\title{
Hydrogen Production by Steam Reforming of Glycerol using Magnesium Promoted Nickel, Cobalt-Alumina Catalysts
}

\author{
Narasimha Reddy Ravuru ${ }^{1}$, Sanjay Patel ${ }^{2}$ \\ ${ }^{1,2}$ Chemical Engineering Department, Institute of technology, Nirma University \\ ${ }^{1}$ narasimhareddy.ravuru@nirmauni.ac.in
}

\begin{abstract}
The depleting fossil fuels with their ever increasing prices have paved ways for alternative fuels. Use of biodiesel and its production are expected to grow steadily in future. With the increase in production of biodiesel, there would be a glut of glycerol in the world market. Glycerol is a potential feed stock for hydrogen production because one mole of glycerol on steam reforming produces 7 moles of hydrogen. Production of hydrogen from glycerol is environmentally friendly because it adds value to glycerol generated from biodiesel plants. The study focuses on comparison on Cobalt Catalyst and Nickel based catalysts modified with Mg on Alumina support. The catalysts were prepared by the incipient wetness technique. The experiments were carried out using lab scale catalytic reactor and the gas products generated are analyzed in GC. The paper discusses the effect of the catalysts on hydrogen selectivity and Conversion and glycerol conversion ranging from $700^{\circ} \mathrm{C}$ to $900^{\circ} \mathrm{C}$. The effect of glycerol to water ratio, metal loading, temperature and feed flow rate was analyzed. It was found that with the increase in the water to glycerol molar ratio, feed flow rates around $1 \mathrm{ml} / \mathrm{min}$, at $850^{\circ} \mathrm{C}$ maximum hydrogen was produced. The results show that glycerol steam reforming is a viable alternative use of glycerol to produce hydrogen. A Theory regarding Kinetic Study and Characterisation of Liquid samples has been studied.
\end{abstract}

Keywords: Glycerol, Hydrogen, Steam Reforming, Promoted Catalyst, Characterisation

\section{INTRODUCTION}

Due to ever increasing consumption of Fossil fuels, there has been an utmost need for development of Alternative fuels which would be fuels for future. Also, these fuels have to be Environment friendly and should cause less pollution. The need for Greener fuels and Zero Emission discharge has led to tremendous increase in Research and experimentation. One of the methods having higher potential for production of Hydrogen is from Glycerol. Glycerol is obtained from Bio-Diesel (which itself is used as an alternate fuel) as a by-Product [1]. For 10 Moles for Bio-Diesel produced, 3 moles of Glycerol is produced. This Glycerol is converted to Hydrogen Via Steam reforming Method. Thermodynamically, the reaction is more favorable at a higher temperature from $650-950^{\circ} \mathrm{C}[2-4]$. Extensive research has been carried out at varying temperature, pressure, Flow rates, catalysts (Supported, Promoted) and potential results have been obtained. Steam Reforming Method Stoichometrically yields 7 moles of Hydrogen, but practically around 4-5 moles of Hydrogen is produced [5]. While experimentation it has been observed that not on numerous gases but different liquids are also obtained, making the study of Kinetics extremely difficult to study [6]. The steam reforming reaction of glycerine proceeds according to the following equations:

Steam reforming of glycerine:

$\mathrm{C}_{3} \mathrm{H}_{8} \mathrm{O}_{3(\mathrm{~g})}+3 \mathrm{H}_{2} \mathrm{O}_{(\mathrm{g})} \rightleftharpoons 3 \mathrm{CO}_{2(\mathrm{~g})}+7 \mathrm{H}_{2(\mathrm{~g})}$

Reverse Water gas shift reaction:

$\mathrm{CO}_{(\mathrm{g})}+\mathrm{H}_{2} \mathrm{O}_{(\mathrm{g})} \rightleftharpoons \mathrm{CO}_{2(\mathrm{~g})}+\mathrm{H}_{2(\mathrm{~g})}$

Methanation reaction:

$\mathrm{CO}_{(\mathrm{g})}+3 \mathrm{H}_{2(\mathrm{~g})} \rightarrow \mathrm{CH}_{4(\mathrm{~g})}+\mathrm{H}_{2} \mathrm{O}_{(\mathrm{g})}$

$\mathrm{CO}_{2}$ Methnation Reaction:

$\mathrm{CO}_{2(\mathrm{~g})}+4 \mathrm{H}_{2(\mathrm{~g})} \rightarrow \mathrm{CH}_{4(\mathrm{~g})}+2 \mathrm{H}_{2} \mathrm{O}(\mathrm{l})$

\section{EXPERIMENTAL WORK}

A. Catalyst preparation:

D-Block elements favors as catalyst as they have 3-4 electrons in their outermost orbital and can be linked easily. Using Catalyst does not only decrease the activation energy but increases the conversion. Catalyst can be 
prepared by numerous methods each giving different results (Keeping the other parameters constant). Catalyst on which experimentation was carried out were prepared by Incipent-Wetness method. Non-promoted catalyst of Cobalt over $\gamma-\mathrm{Al}_{2} \mathrm{O}_{3}$ (Support) and Magnesium promoter on Nickel over $\gamma-\mathrm{Al}_{2} \mathrm{O}_{3}$ (Support) were studied. Both the catalyst were Impregnated on $\mathrm{y}-\mathrm{Al}_{2} \mathrm{O}_{3}$ (Support) after which it were shaked for 4 hrs so a proper mixture is obtained. Overnight Drying at $120-140^{\circ} \mathrm{C}$ so that no moisture is left, which is followed by Calcination at $450^{\circ} \mathrm{C}$ for $3 \mathrm{hrs}$ [3]. Calcination determines the pore size, Porosity, Surface area of the catalyst and thus it is the most important step. The following table shows the catalyst with different compositions.

TABLE I Catalyst used in Production of Hydrogen

\begin{tabular}{|c|c|c|c|c|c|}
\hline Catalyst & Percentage & $\begin{array}{c}\text { Percentage of } \\
\text { Promoter }\end{array}$ & $\begin{array}{c}\text { Amount of } \\
\text { Promoter }\end{array}$ & $\begin{array}{c}\text { Amount of } \\
\text { Precursor }\end{array}$ & $\begin{array}{c}\mathrm{Amount}^{\text {of } \gamma^{-}} \\
\mathrm{Al}_{2} \mathrm{O}_{3}\end{array}$ \\
\hline Nickel & $5 \%$ & - & - & 1.23 & 4.75 \\
\hline Nickel & $10 \%$ & - & - & 2.46 & 4.5 \\
\hline $\mathrm{Nickel}$ & $15 \%$ & - & - & 3.69 & 4.25 \\
\hline $\mathrm{Ni} / \mathrm{Mg}$ & $5 \%$ & $2 \%$ & 0.933 & 2.16 & 4.65 \\
\hline $\mathrm{Ni} / \mathrm{Mg}$ & $10 \%$ & $2 \%$ & 0.933 & 3.393 & 4.4 \\
\hline $\mathrm{Ni} / \mathrm{Mg}$ & $15 \%$ & $2 \%$ & 0.933 & 4.623 & 4.1 \\
\hline
\end{tabular}

\section{B. Experimental setup}

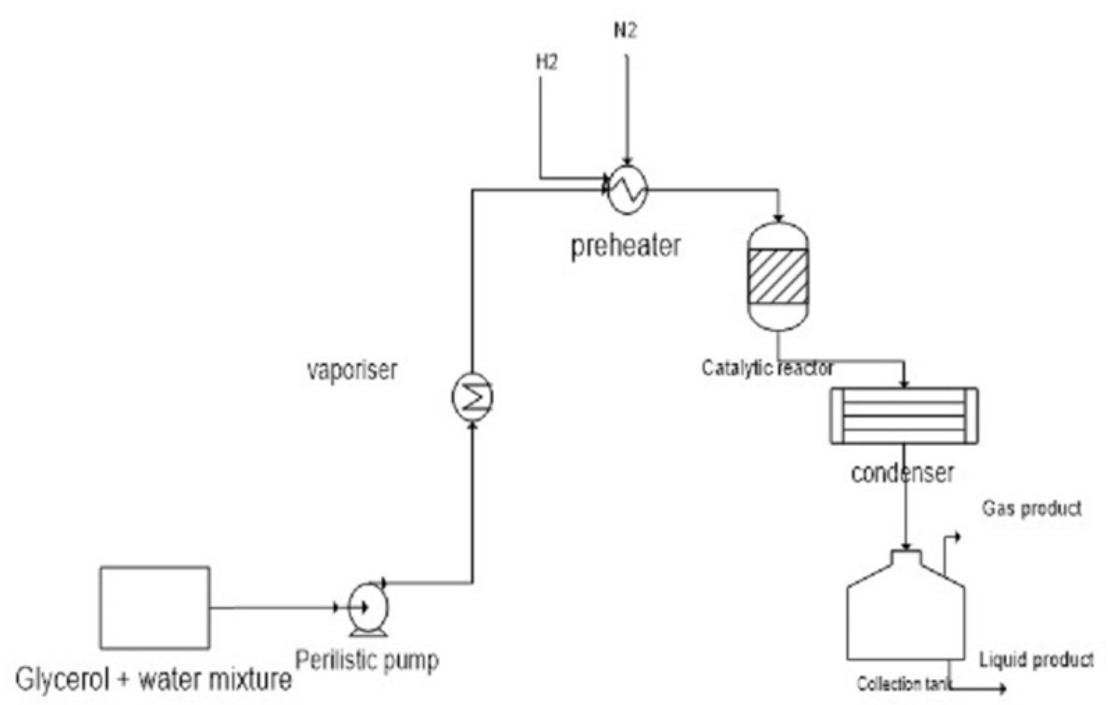

Fig.1. Schematic of glycerol steam reforming setup [7]

\section{Reaction condition}

The best thermodynamic condition for hydrogen production by steam reforming of glycerol is at a temperature above $650^{\circ} \mathrm{C}$.

TABLE II Operating Condition

\begin{tabular}{|c|c|}
\hline Operating Pressure & 1 atmosphere \\
\hline Operating Temperature & $500{ }^{\circ} \mathrm{C}$ to $900{ }^{\circ} \mathrm{C}$ \\
\hline Weight of catalyst & $1-1.1$ gram \\
\hline Flow rate of (glycerol + water) & $3 \mathrm{ml} /$ minute \\
\hline Molar ratios of water to glycerol & $9: 1,12: 1,15: 1,18: 1$ \\
\hline $\mathrm{H}_{2}: \mathrm{N}_{2}$ (flow rates) & $15: 85$ \\
\hline Flow rate of $\mathrm{H}_{2}$ & $50 \mathrm{ml} / \mathrm{minute}$ \\
\hline Flow rate of $\mathrm{N}_{2}$ & $283 \mathrm{ml} /$ minute \\
\hline
\end{tabular}

\section{Results and Discussion}

Assuming Mole $\%=$ Volume $\%$, Gas Chromatography graphs are obtained when Glycerol-Water are injected at Flow-rate of $4.8 \mathrm{ml} / \mathrm{min}$ through peristaltic pump. The reactor bed is installed with catalyst bed and heated through furnace at varying temperatures. Gas samples are separated from Liquid samples in separator and analysis are carried out in Gas Chromatography. Liquid samples are tested in HPLC. 
From the experiments it seems that the desired temperature for getting maximum conversion is around 800 ${ }^{0} \mathrm{C}$ to $900{ }^{\circ} \mathrm{C}$. Glycerol to water mole ratio in the feed is $2: 8$.Increase in ratio up-to $1: 12,1: 15$ or 1:18 then hydrogen production is going to be increased because as per le-chetelier principle. [8-9]

\section{A. Temperature effect on Conversion:}

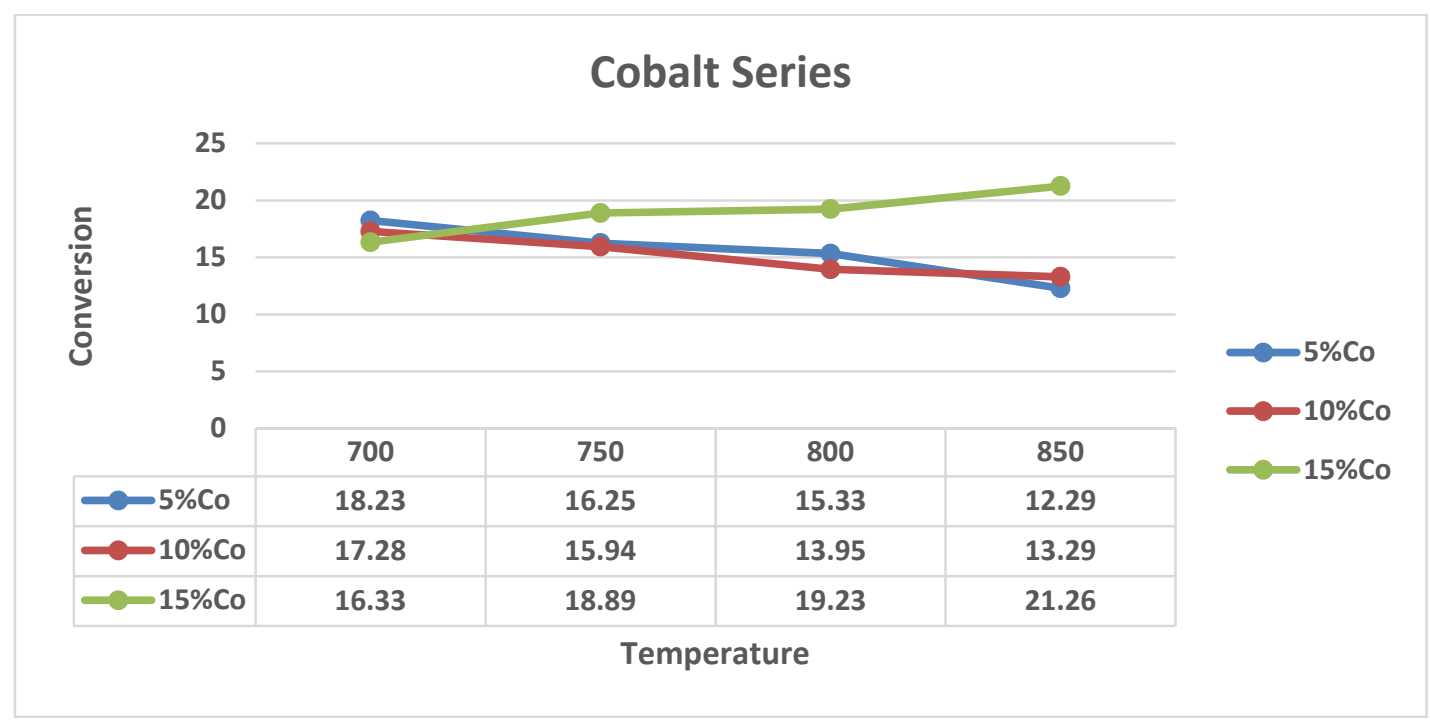

Fig. 2. Conversion of Hydrogen using Cobalt as Catalyst:

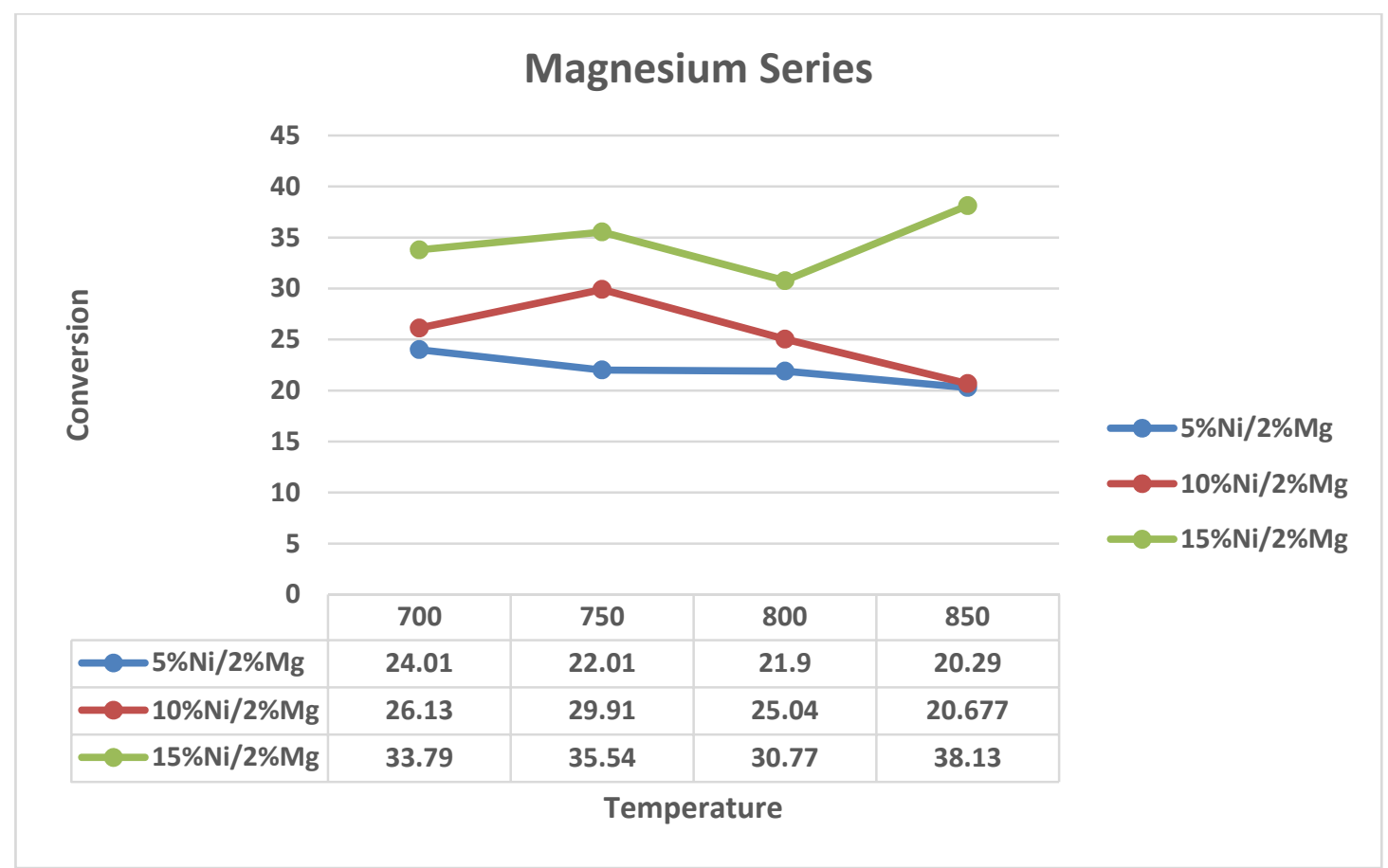

Fig. 3. Conversion of Hydrogen from Magnesium promoted Nickel Catalyst 
B. Temperature effect on Selectivity:

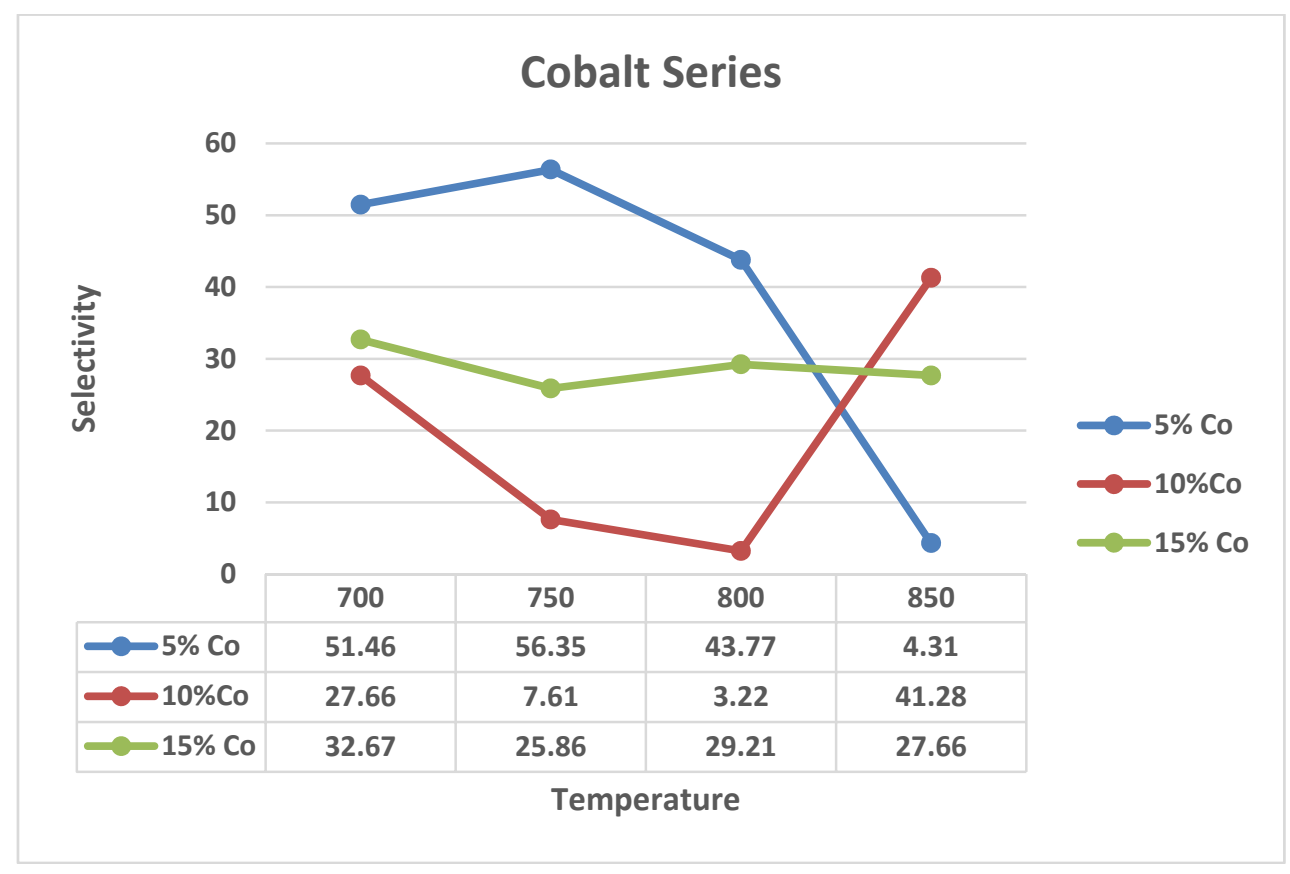

Fig. 4. Selectivity of Hydrogen using Cobalt as catalyst

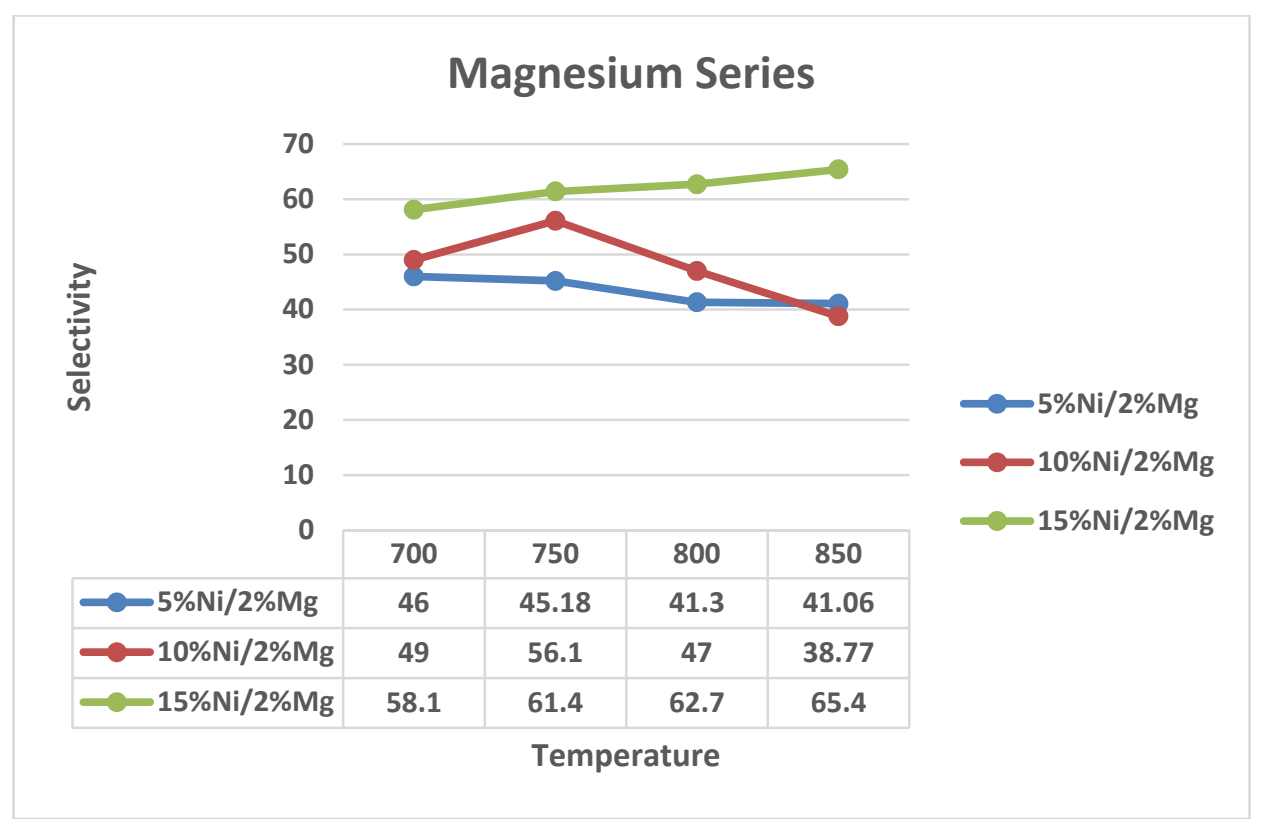

C. Kinetics:

Fig. 5. Selectivity of Hydrogen from Magnesium promoted Nickel Catalyst

Causing of Numerous Gaseous Products $\left(\mathrm{H}_{2}, \mathrm{CO}, \mathrm{N}_{2}, \mathrm{CH}_{4}\right.$ and $\left.\mathrm{CO}_{2}\right)$ and different Liquid phases (Acetaldehyde, Acetonitrile, Ethanol, Methanol, un-converted Glycerol-Water) in varying Compositions it becomes extremely difficult to obtain the Equilibrium Constants. [10].

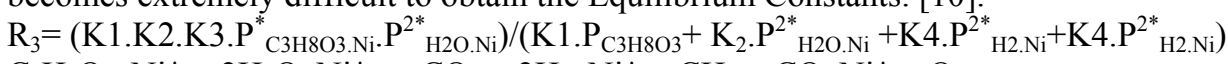

$\mathrm{C}_{3} \mathrm{H}_{8} \mathrm{O}_{3} . \mathrm{Ni}^{*}+2 \mathrm{H}_{2} \mathrm{O} . \mathrm{Ni}^{*} \rightarrow \mathrm{CO}_{2}+2 \mathrm{H}_{2} . \mathrm{Ni}^{*}+\mathrm{CH}_{4}+\mathrm{CO} . \mathrm{Ni}^{*}+\mathrm{O}_{2}$ 
Theory Proposed: Three Active sites are made available. The Five gases (Carbon Dioxide, Hydrogen, Methane, Carbon Monoxide and Oxygen) that are produced are the result of Five Step Mechanism (Adsorption, Reaction and Desorption). The Production of this gases depends upon the "AFFINITY" of the Catalyst with the reactant at a given temperature and pressure. The Affinity of Production of Hydrogen is comparatively less when compared with carbon Monoxide.

$$
\mathrm{CO}+\mathrm{H}_{2} \mathrm{O} \underset{\text { High T:rev:WGS }}{\stackrel{\text { Low T:WGS }}{\leftrightarrows}} \mathrm{CO}_{2}+\mathrm{H}_{2}
$$

The above figure shows that, Favouring High Temperature, may obtain higher Conversion but will drastically reduce the Selectivity and vice-versa. Thus an optimum Temperature must be obtained to balance conversion and selectivity [11].

\section{Feed Flow Rate:}

The steam reforming process is reversible and endothermic. Therefore, product formation is very less because the product is again converted into reactants. As per le-chatelier principle increase in the concentration of one of reactant means add one of the reactant in to excess mole percentage other than required. So, increase in the concentration of glycerol or water then there is no byproduct formation and conversion is going to be increased. The water is add as an excess reactant because compare to glycerol water is too cheaper. The unreacted glycerol in product is going to be decreased and we can get maximum conversion of glycerol.

\section{E. Effect of feed flow rate and residence time}

For the steam reforming process it is desired that the feed flow rate must be minimal and for all the reactions residence time must be increased. If feed flow rate of glycerol water mixture is minimum then mixture is passed very slowly from the reactor tube and residence time is going to be increased. If the residence time is going to be increased then collision frequency between molecules of glycerol and water is increased and reaction going towards forward direction and by-product formation or amount of unreacted glycerol is going to be decreased.

\section{CONCLUSION}

Steam reforming of glycerol has been studied at different temperature conditions and different compositions and correspondingly comparisons have been made between Cobalt and Magnesium promoted Nickel Catalyst. From the experimental studies it was conclude that as compositions of Cobalt increases in catalyst, Conversion of hydrogen increases while its selectivity is highly unstable for increasing temperatures. For Magnesium promoted Nickel Catalyst, Conversion increases above $800^{\circ} \mathrm{C}$ for $15 \% \mathrm{Ni} / 2 \% \mathrm{Mg}$ while for other promoted catalyst it decreases. Also, Selectivity Maximum for $15 \% \mathrm{Ni} / 2 \% \mathrm{Mg}$ increases with increase in temperature while for others it increases and then fairly decreases. From the experimental studies the optimum temperature is $850^{\circ} \mathrm{C}$ for obtaining maximum Conversion and Selectivity for $15 \% \mathrm{Ni} / 2 \% \mathrm{Mg}$ and WGFR is $8: 2$ at feed flow rate of $4.8 \mathrm{ml} /$ minute. From the experimental studies it seems to be clear that high temperature, low pressure and high water to glycerol feed ratio is the best conditions for getting higher yield of hydrogen.

\section{References}

[1] S. Adhikari, D. Fernando, A. Haryanto, "Hydrogen production from glycerol: An update", Energy Conversion and Management 50, 2009, 2600-04.

[2] S. Adhikari, D. Fernando, A. Haryanto , "A comparative thermodynamic and experimental analysis on hydrogen production by steam reforming of glycerin". Energy Fuel, 2007, 21(4):2306-10.

[3] C. Bartholomew, R. Farrauto, "Fundamental of industrial catalytic processes", Wiley publication, 2nd edition, pg no.:91-180.

[4] N. Luo, X. Zhao, F. Cao, T. Xiao, and D. Fang, "Thermodynamic Study on Hydrogen Generation from Different Glycerol Reforming Processes" Energy \& Fuels, 2007, 21, 3505-12.

[5] Adhikari S, Fernando S, Haryanto A, Production of hydrogen by steam reforming of glycerin over alumina supported metal catalysts. Catal Today, 2007, article in press.

[6] Andre Velente Bueno, Mona Lisa Moura de Oliveira, "Glycerol steam reforming in a bench scale continuous flow heat recovery reactor", International Journal of Hydrogen Energy, 2013, 13991-14001.

[7] Hirai T, Ikenaga NO, Mayake T, Suzuki T. Production of hydrogen by steam reforming of glycerin on rutheniumon ruthenium catalyst .Energy Fuels2005; 19:1761-2.

[8] Binlin Dou Yongchen Song Chao Wang Haisheng Chen Yujie Xu, "Hydrogen production from catalytic steam reforming of biodiesel byproduct glycerol: Issues and challenges", Renewable and Sustainable Energy reviews 30, 2014, 950-960.

[9] Thirasak Pairojpiriyakul Eric Croiset Worapon Kiatkittipong Kunlanan Kiatkittipong Amornchai Arpornwichanop Suttichai Assabumrungrat, "Hydrogen production from catalytic supercritical water reforming of glycerol with cobalt-based catalysts" International Journal of Hydrogen Energy, 2013, 4368-4379.

[10] M.L. Dieuzeide V. Iannibelli M. Jobbagy N. Amadeo, "Steam reforming of glycerol over Ni/Mg/g- $\mathrm{Al}_{2} \mathrm{O}_{3}$ catalysts. Effect of calcination temperatures", International Journal of Hydrogen Energy 37, 2012, 14926- 14930.

[11] Sanjay Patel, K.K. Pant, Hydrogen production by oxidative steam reforming of methanol using ceria promoted copper-alumina catalysts, Fuel Processing Technology, 88, 2007, 825-832.

\section{AUTHOR PROFILE}


Narasimhareddy Ravuru is working as an Assistant Professor in Chemical Engineering Department of Institute of Technology in Nirma University, Ahmedabad. He has obtained his B.Tech. in Chemical Engineering from Madras University in the year 2000 and Masters in Chemical Engineering from The IIT, Madras in year 2006. His research interest includes Catalysis. He is a Life member of ISTE. He is having teaching experience of 16 years.

Sanjay Patel is working as a Professor in Chemical Engineering Department of Institute of Technology in Nirma University, Ahmedabad. He has obtained his B.E. in Chemical Engineering from DDIT, Nadiad in the year 1997 and Masters in Chemical Engineering from The IIT, Delhi in year 2004. He has completed his Ph.D. from IIT, Delhi in year 2007. His research interest includes Catalysis. He is a Life member of ISTE. He is having teaching experience of 20 years. 